\title{
Turtles of the Tiputini Biodiversity Station with remarks on the diversity and distribution of the Testudines from Ecuador
}

\author{
Diego F. Cisneros-Heredia ${ }^{1}$ \\ Biota Neotropica v6 (n1)-http://www.biotaneotropica.org.br/v6n1/pt/abstract?inventory+bn00906012006 \\ Date Received 05/23/2005 - Revised 10/18/2005 - Accepted 01/01/2006 \\ ${ }^{1}$ College of Biological and Environmental Sciences, Universidad San Francisco de Quito, Casilla Postal 17-12-841 Quito, \\ Ecuador. E-mail: diegofrancisco_cisneros@yahoo.com
}

\begin{abstract}
Cisneros-Heredia, D.F. Turtles of the Tiputini Biodiversity Station with remarks on the diversity and distribution of the Testudines from Ecuador. Biota Neotrop. Jan/Abr 2006, vol. 6, no. 1 http://www.biotaneotropica.org.br/v6n1/pt/ abstract?inventory+bn00906012006. ISSN 1676-0611

Ten species of Testudines, from four different families: Chelidae, Kinosternidae, Podocnemididae, and Testudinidae, are reported from the Tiputini Biodiversity Station (Universidad San Francisco de Quito), northeastern Amazonian Ecuador; including the second report from Ecuador of Batrachemys heliostemma. These ten species are sympatric but not completely syntopic, thus I comment on their diversity and habitat preferences patterns. The general distribution of some turtles from Amazonian Ecuador is discussed, providing additional records and distribution maps for Chelus fimbriatus, Platemys platycephala, Batrachemys heliostemma, Batrachemys raniceps, Mesoclemmys gibba, Phrynops geoffroanus, Kinosternon scorpioides, and Geochelone denticulata. The presence of Peltocephalus dumerilianus in Amazonian Ecuador is confirmed; based on re-examination of specimens previously reported by Dr. Gustavo Orcés in 1949. The total Ecuadorian richness of Testudines species includes 31 living taxa, and I provide an annotated list of the turtles and tortoises of mainland and insular Ecuador. Much information is still needed in order to understand the ecological relationships of the Testudines from Ecuador and future research should focus on long-term studies designed to answer several questions about their biology and ecology. Several threats are currently jeopardizing the long-term conservation of turtle populations in Ecuador, and we must increase our knowledge on these amazing animals in order to protect and preserve them.

Key words: Reptilia, Testudines, Chelidae, Kinosternidae, Podocnemididae, Testudinidae, Chelus fimbriatus, $\underline{\text { Platemys }}$ platycephala, Batrachemys heliostemma, Batrachemys raniceps, Mesoclemmys gibba, Phrynops geoffroanus, Kinosternon scorpioides, Geochelone denticulata, Podocnemis expansa, Podocnemis unifilis, Peltocephalus dumerilianus, diversity, habitat preferences, distribution, checklist, Amazonia, Ecuador
\end{abstract}

\section{Resumen}

Cisneros-Heredia, D.F. Las Tortugas de la Estación de Biodiversidad Tiputini con notas sobre la distribución de alginos Testudines de Ecuador. Biota Neotrop. Jan/Abr 2006, vol. 6, no. 1http://www.biotaneotropica.org.br/v6n1/pt/ abstract?inventory+bn00906012006. ISSN 1676-0611

Diez especies de Testudines, de cuatro familias diferentes: Chelidae, Kinosternidae, Podocnemididae, y Testudinidae, son reportadas de la Estación de Biodiversidad Tiputini (Universidad San Francisco de Quito), en la Amazonía Nororiental de Ecuador; incluyendo el segundo reporte para Ecuador de Batrachemys heliostemma. Estas diez especies son simpátricas pero no completamente sintópicas, por lo que comento sobre sus patrones de diversidad y preferencias de hábitat. La distribución general de algunas especies de tortugas de la Amazonía de Ecuador es discutida, proveyendo registros adicionales y mapas de distribución para Chelus fimbriatus, Platemys platycephala, Batrachemys heliostemma, Batrachemys raniceps, Mesoclemmys gibba, Phrynops geoffroanus, Kinosternon scorpioides, y Geochelone denticulata. La presencia de Peltocephalus dumerilianus en la Amazonía de Ecuador es confirmada; basada en la reexaminación de especímenes previamente reportados por el Dr. Gustavo Orcés en 1949. La riqueza total de especies de tortugas en Ecuador incluye 31 taxa vivientes; proveo una lista anotada de las especies de tortugas de Ecuador continental e insular. Mucha información es aún requerida para poder comprender las relaciones ecológicas de los Testudines de Ecuador e investigaciones futuras deberían enfocarse en estudios a largo plazo diseñados para responder a varias preguntas sobre su biología y ecología. Algunos peligros amenazan la conservación a largo plazo de las poblaciones de tortugas de Ecuador y debemos incrementar nuestro conocimiento sobre estos sorprendentes animales para poder protegerlos y conservarlos.

Palabras-clave:Reptilia, Testudines, Chelidae, Kinosternidae, Podocnemididae, Testudinidae, Chelus fimbriatus,

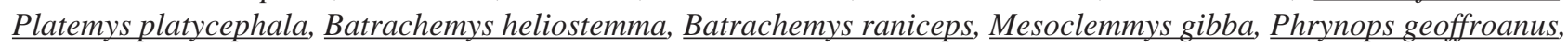
Kinosternon scorpioides, Geochelone denticulata, Podocnemis expansa, Podocnemis unifilis, Peltocephalus dumerilianus, diversidad, preferencias de hábitat, distribución, lista, Amazonia, Ecuador 


\section{Introduction}

Thirty taxa of living Testudines have been recognized for Ecuador (Miyata 1982, Pritchard \& Trebbau 1984, Almendáriz 1991, Coloma et al. 2000-2004); four species are marine turtles, 11 taxa correspond to the endemic giant tortoises of the Galapagos Archipelago (McFarland et al. 1974), and 15 species occur in mainland Ecuador. Five mainland taxa are restricted to the Pacific lowlands of Ecuador, including one member of the family Kinosternidae (Kinosternon leucostomum Duméril \& Bibron) and all Ecuadorian members of the families Chelydridae (1 sp.: Chelydra serpentina [Linnaeus]) and Geoemydidae (3 spp.: Rhinoclemmys annulata [Gray], R. melanosterna [Gray], and R. nasuta [Boulenger]). The greatest diversity of Testudines in mainland Ecuador occurs in the Amazonian lowlands; unfortunately little information is available on most turtles from mainland Ecuador, and although most Amazonian taxa are conceived as widespread, little data exists on its distribution and ecology. The objective of this paper is to make an initial approach oT the testudines diversity in Ecuador, with some remarks on the distribution of the Testudines from Amazonian Ecuador, compiling every record from Amazonian Ecuador, presenting some specific data on the diversity and habitat preferences of the turtles and tortoise from the Tiputini Biodiversity Station; and an annotated list of the turtles and tortoises of mainland and insular Ecuador.

\section{Materials and Methods}

Field work was done at the Tiputini Biodiversity Station, (TBS - 00³7’05" S, 76¹0'19" W, $190-270$ m a.s.l.), a research station located in the province of Orellana, Republic of Ecuador, ca. 280 km ESE from Quito; in the northern bank of the Tiputini River, part of the Napo and Amazonas Rivers Basins. TBS was established in 1995 by the Universidad San Francisco de Quito (Ecuador), in cooperation with Boston University (USA), as a center of education, research and conservation. TBS is adjacent to the Yasuní National Park and it is part of the Yasuní Biosphere Reserve.

TBS preserves a tract of 650 hectares which mostly includes primary Terra Firme forest (Lowland Evergreen Forest), but there is a rather narrow belt of flooded vegetation of Varzea (Lowland Evergreen Forest flooded by whitewaters) and Igapó (Lowland Evergreen Forest flooded by black-waters) towards the river, streams, and around an small oxbow lake. Along the Tiputini River, several beaches are uncovered during the dry season, but all are short, never greater than $100 \mathrm{~m}$.

Herpetological work at TBS was conducted between 1997 and 2001, with 11 human/months. Turtles were surveyed by day and night with through encounters technique (Heyer et al. 1994), especially on the wetlands (swamps, rivulets, streams, oxbow lake, and river). Some specimens were examined and later released to confirm their identities. Individuals not captured (especially those observed while basking over logs in the lake and river) were examined using 10x42 Swarovski binoculars in order to determine its identification. Additional specimens of Ecuadorian Testudines were examined from the collection of the Fundación Herpetológica G. Orcés, Quito (FHGO).

\section{Results and Discussion}

The family Chelidae is represented at TBS by six species, including Chelus fimbriatus (Schneider), Platemys platycephala (Schneider), Batrachemys heliostemma McCord, Ouni \& Lamar, Batrachemys raniceps (Gray), Mesoclemmys gibba (Schweigger), and Phrynops geoffroanus (Schweigger). The last four species correspond to the commonly named "toadhead" turtles, all previously classified under the genus Phrynops until the recent reevaluation by McCord et al. (2001).

Batrachemys heliostemma was recorded twice at TBS; one juvenile was observed in August 1999 and a second juvenile was found on February 2001, both at a shallow swamp located behind the oxbow lake of TBS by day. Both individuals showed the yellow facial marks characteristic of the species. The second individual was caught, examined and released; it had a carapace length of $121 \mathrm{~mm}$, maximum plastral length of $100 \mathrm{~mm}$, and carapace width of $92 \mathrm{~mm}$. The habitat where both individuals were observed coincides with descriptions provided by McCord et al. (2001) for Peruvian populations, and supports their hypothesis about the apparent preference of $B$. heliostemma for high non-flooded areas. Batrachemys heliostemma is a recently described species known from the upper Amazon Basin with records in Venezuela, Colombia, Ecuador, Brazil, and Peru (McCord et al. 2001). This species was known in Amazonian Ecuador from only one locality, "Mariam" in the province of Sucumbíos, Ecuador, collected in October 1983 (McCord et al. 2001). TBS is the second locality for the species in Ecuador, and the westernmost record of the species (Figure 1).

Batrachemys raniceps was recorded twice at TBS, both on the border of the small drainage connecting the oxbow lake and the Tiputini River by day (both examined and later released). One individual of Mesoclemmys gibba was found at TBS while walking ca. $10 \mathrm{~m}$ away from the Tiputini River, on an ephemeral marsh created by a recent flooding; it released a strong-smelling musk when captured (later released). Phrynops geoffroanus was the most common toadhead turtle recorded at TBS; several individuals were observed basking over logs partially submerged at the mouth of a small affluent of the Tiputini River, and along the river itself. In the oxbow lake, at least two individuals were seen partially 


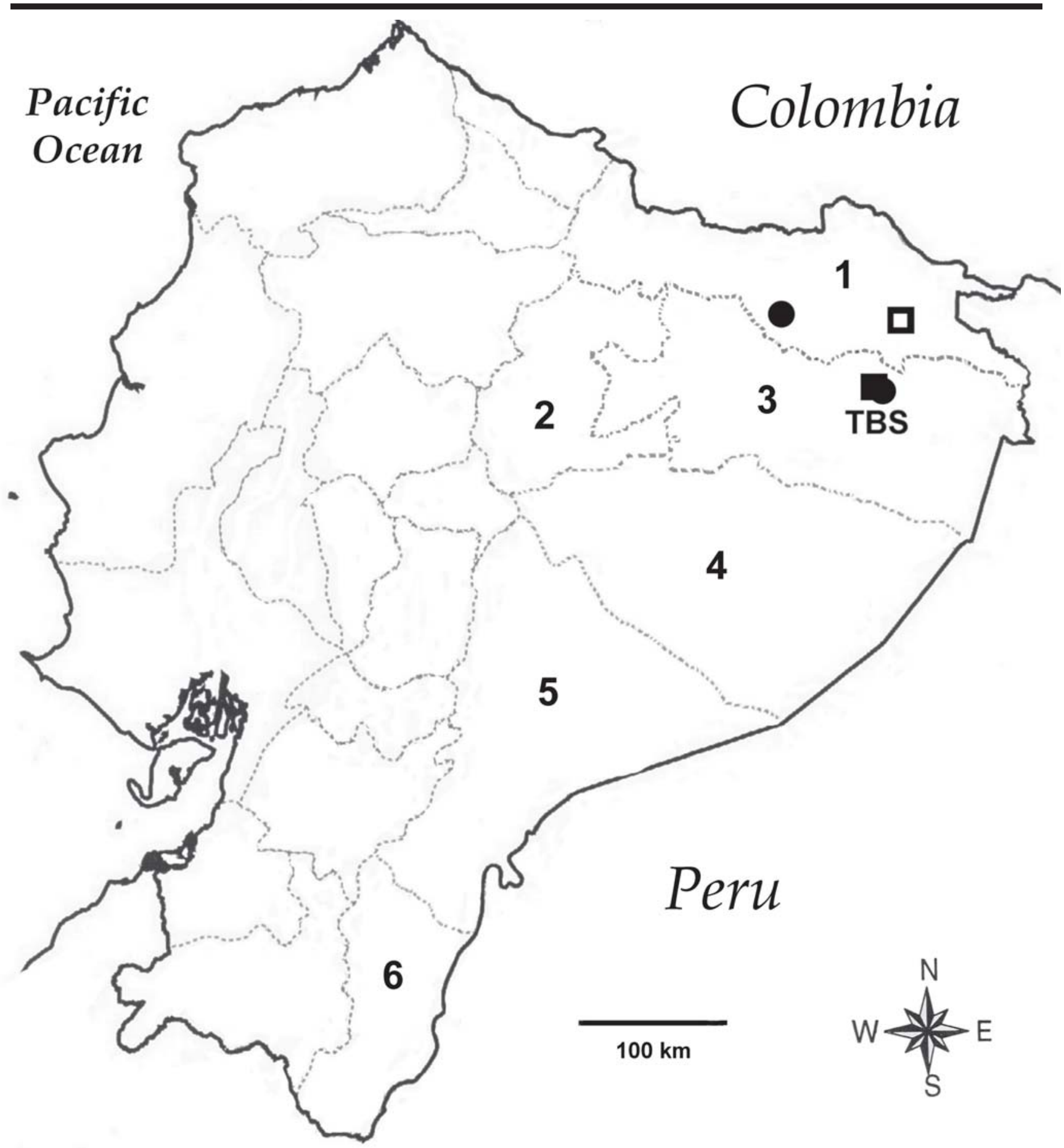

Figure 1. Known records of Batrachemys heliostemma (squares) and Batrachemys raniceps (circles) in the Republic of Ecuador. TBS = Tiputini Biodiversity Station, closed symbols = material studied, open symbols = literature records (see text), numbers correspond to the following provinces in Amazonian Ecuador: $1=$ Sucumbíos, $2=$ Napo, $3=$ Orellana, $4=$ Pastaza, $5=$ Morona-Santiago, $6=$ ZamoraChinchipe.

http://www.biotaneotropica.org.br 


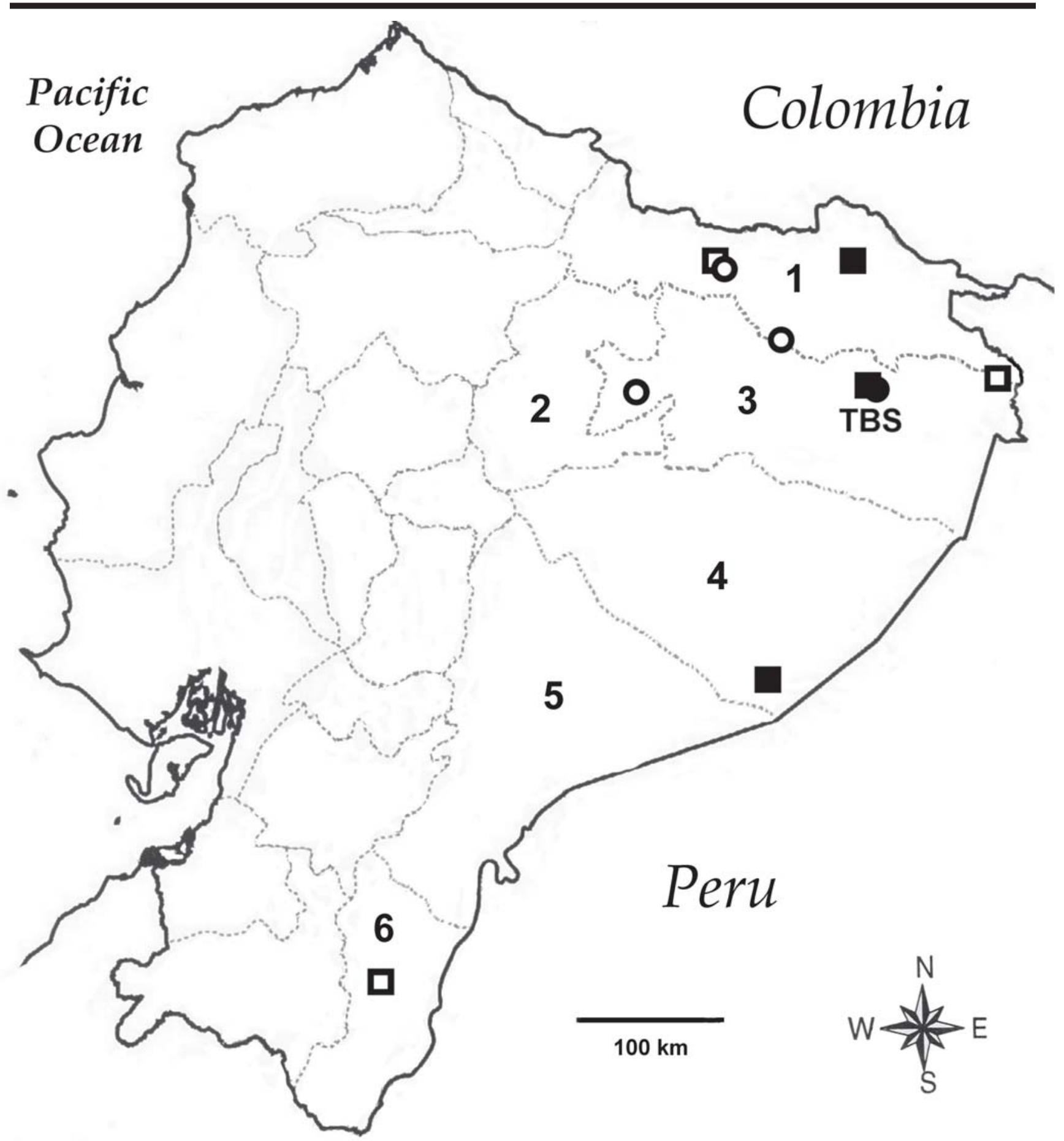

Figure 2. Known records of Chelus fimbriatus (squares) and Kinosternon scorpioides (circles) in the Republic of Ecuador. For symbols equivalence see Figure 1. 


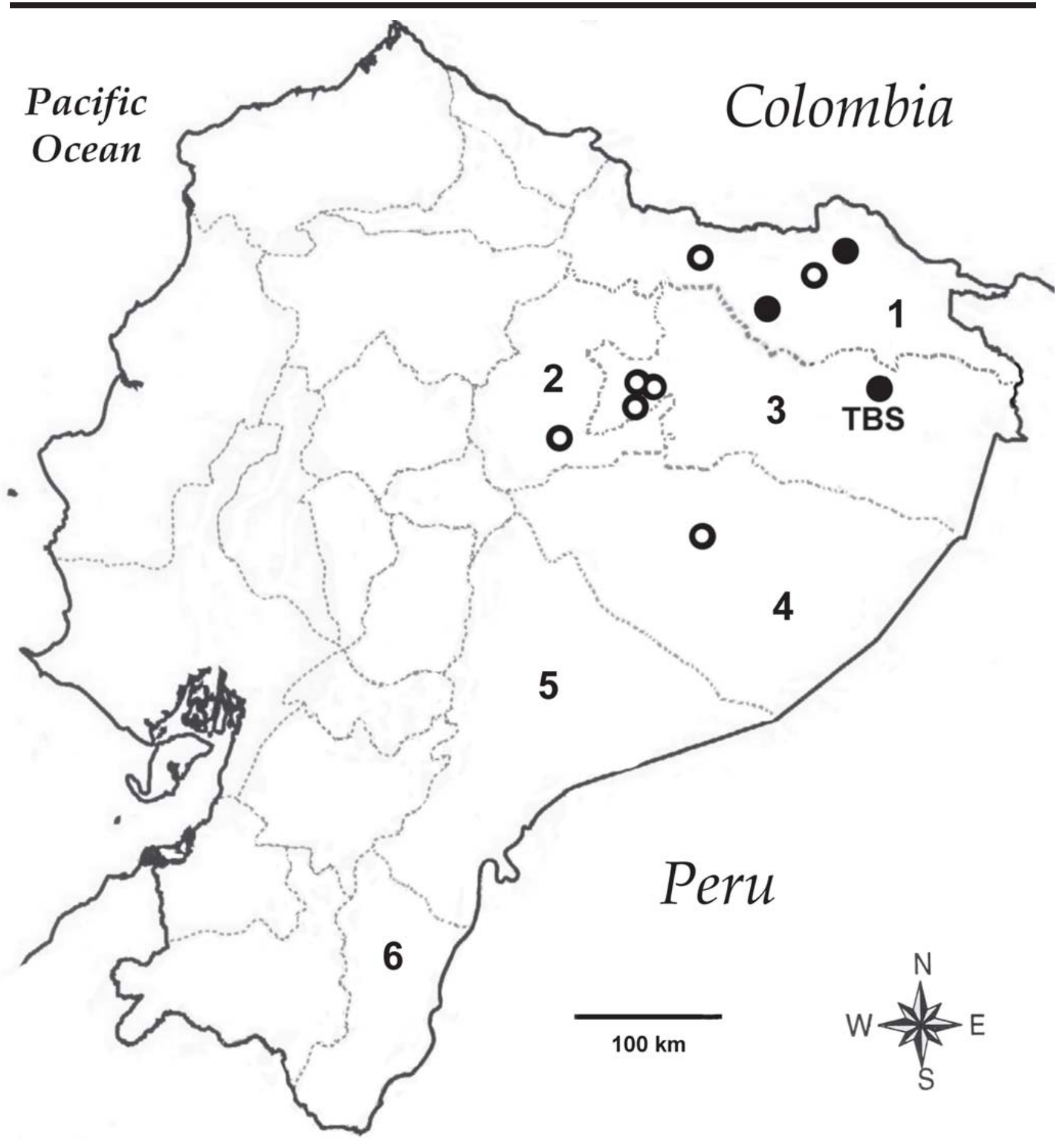

Figure 3. Known records of Mesoclemmys gibba (circles) in the Republic of Ecuador. For symbols equivalence see Figure 1. 


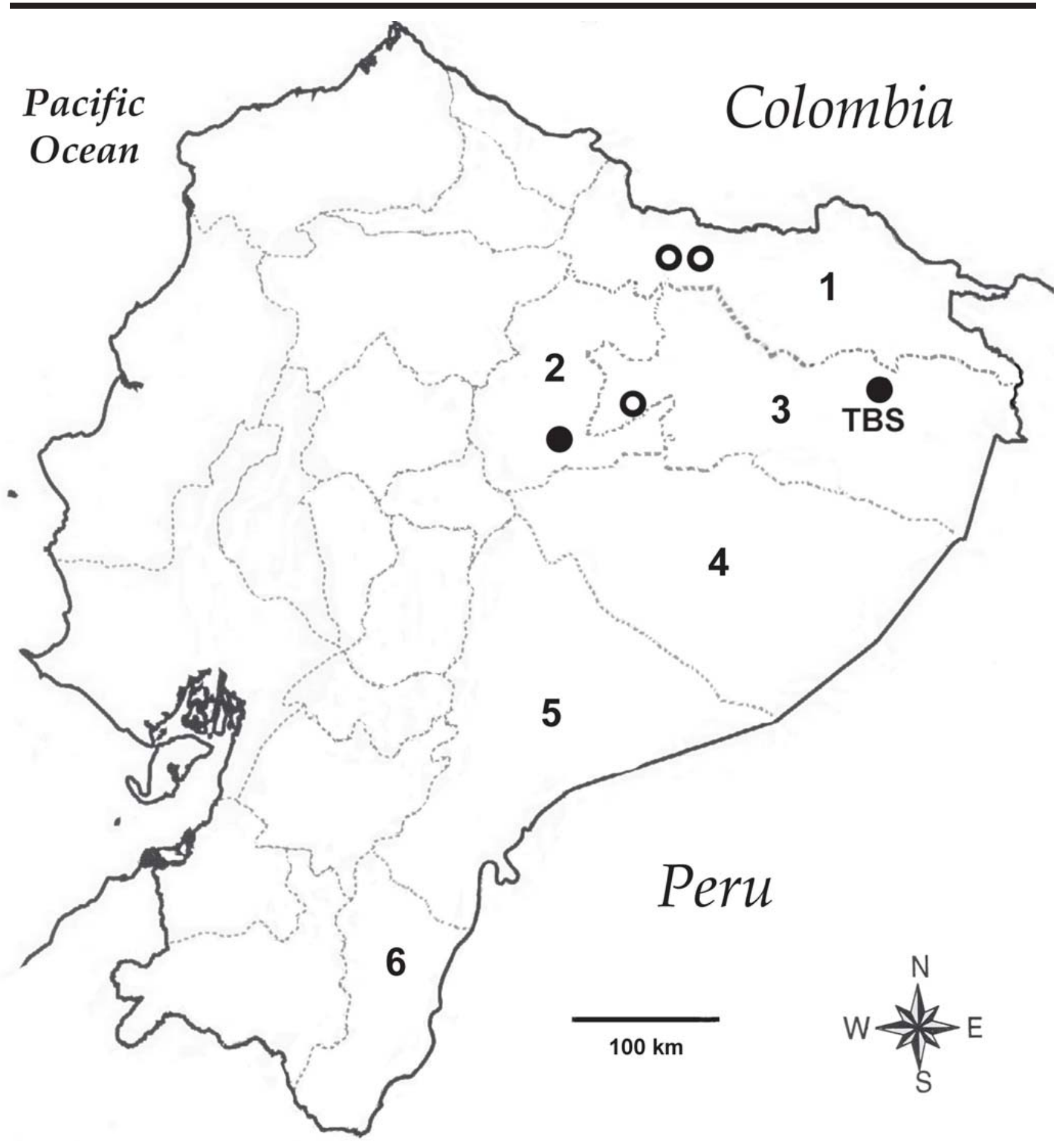

Figure 4. Known records of Phrynops geoffroanus (circles) in the Republic of Ecuador. For symbols equivalence see Figure 1. 


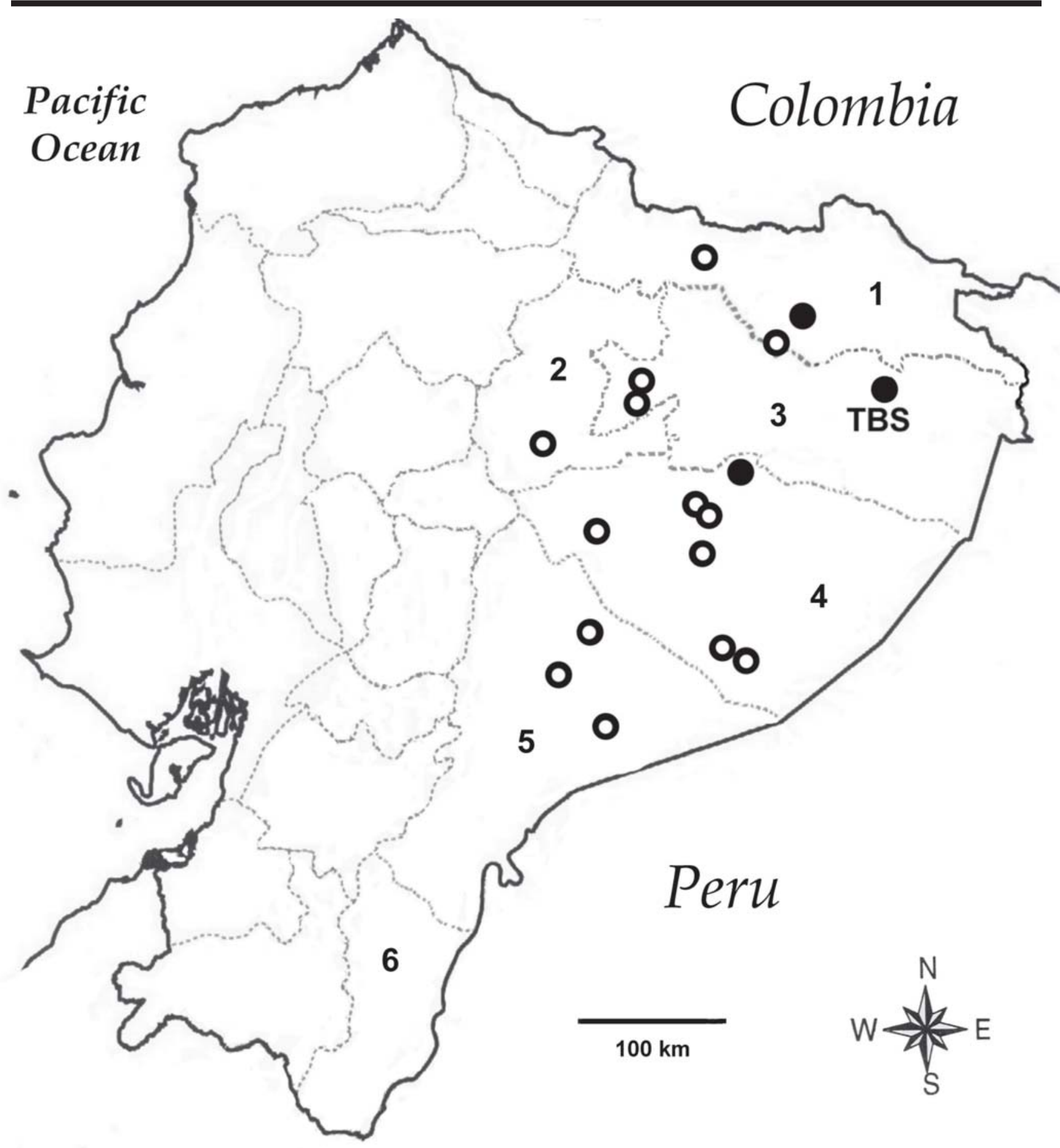

Figure 5. Known records of Platemys platycephala (circles) in the Republic of Ecuador. For symbols equivalence see Figure 1. 


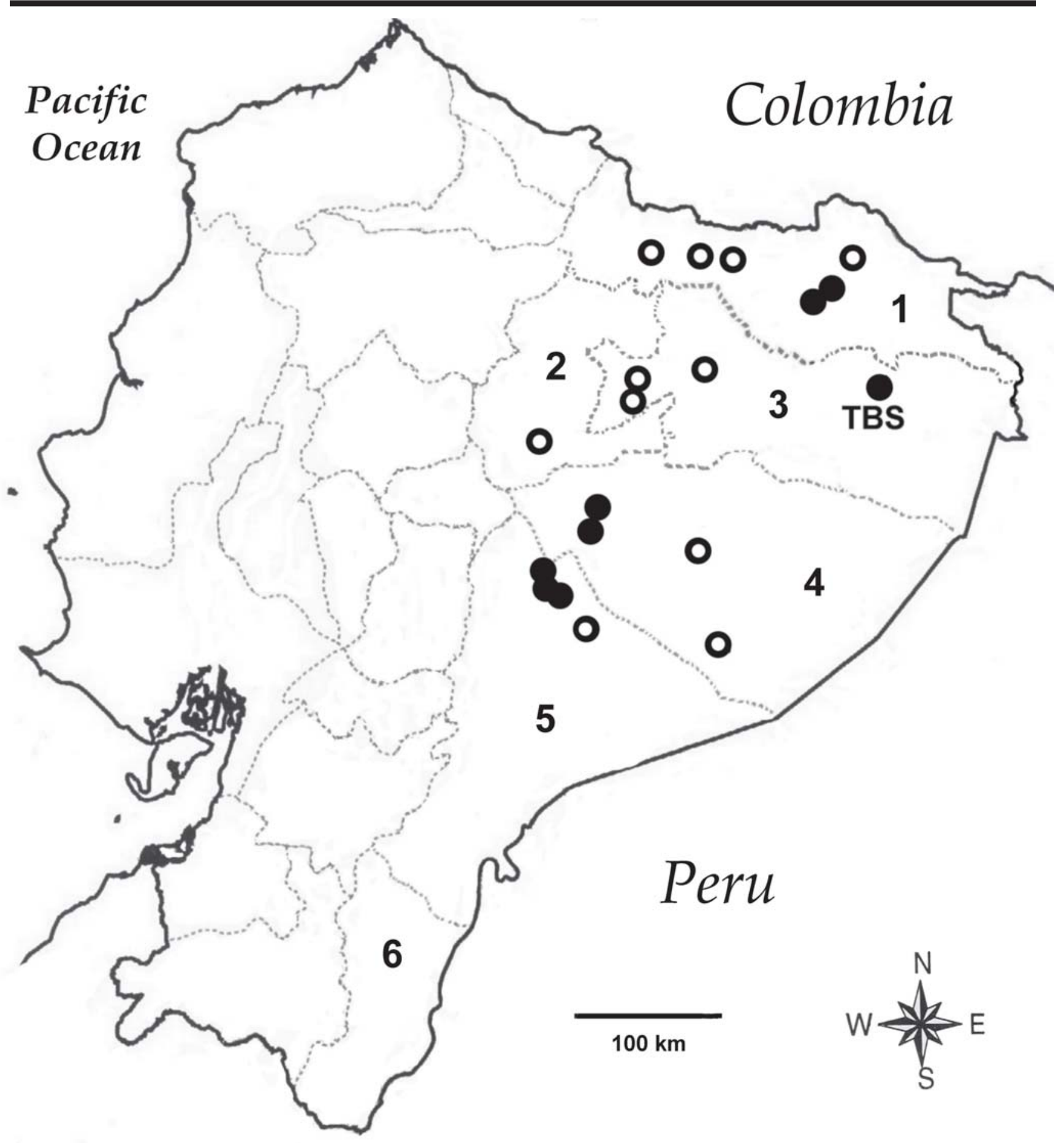

Figure 6. Known records of Geochelone denticulata (circles) in the Republic of Ecuador. For symbols equivalence see Figure 1. 


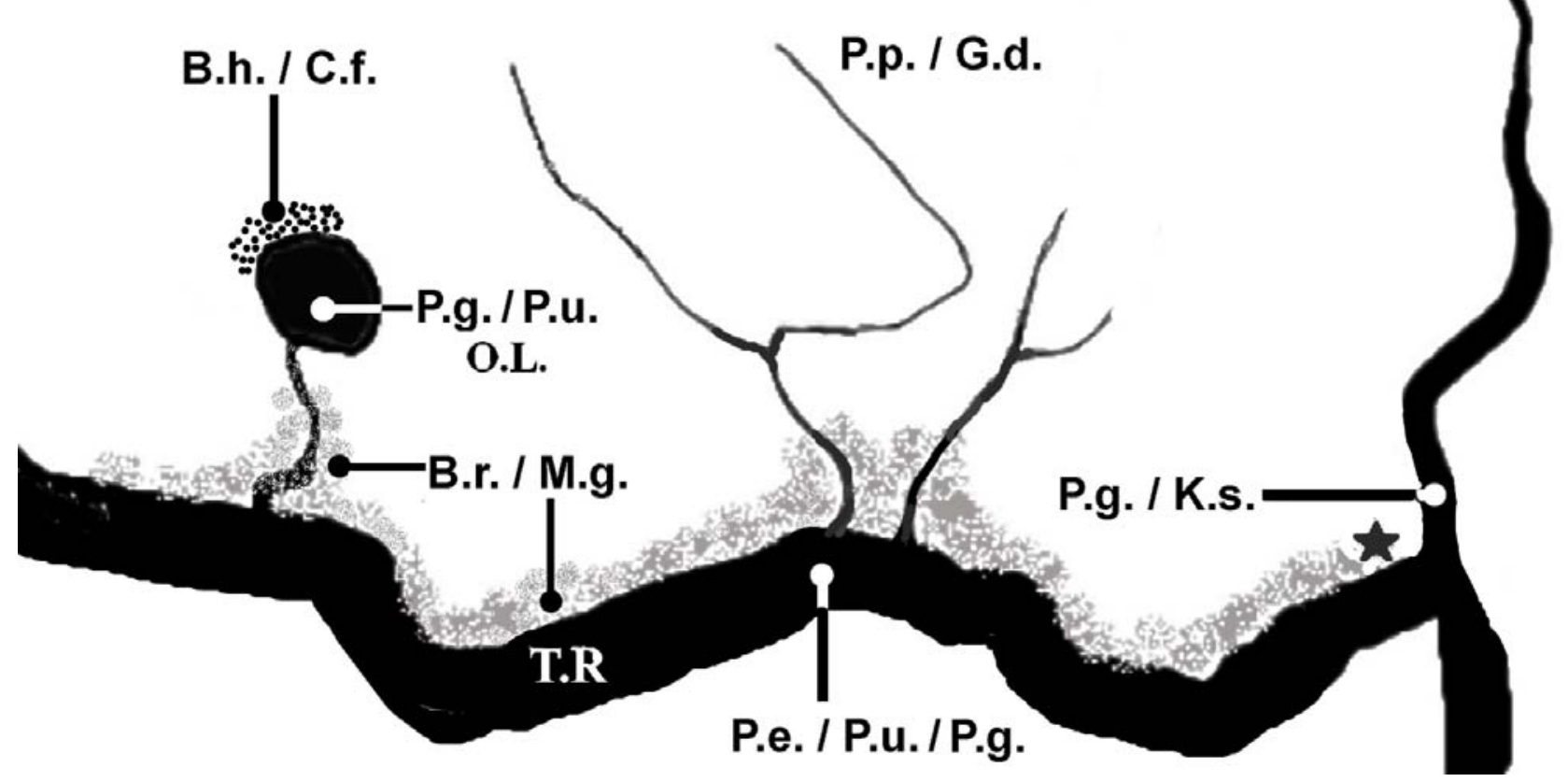

Figure 7. Schematic map of a section of the Tiputini River (T.R.) at the Tiputini Biodiversity Station (station laboratory = star), province of Orellana, Ecuador; indicating habitat preferences by ten chelonian species. O.L. = oxbow lake; dotted area next to oxbow lake = nonseasonally flooded shallow swamp; gray shadow areas = seasonally flooded forest. B.h. = Batrachemys heliostemma: B.r. = Batrachemys

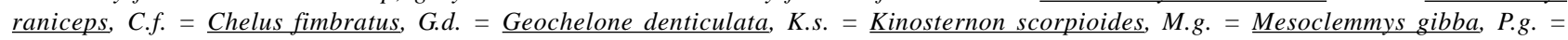

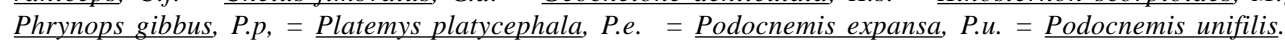

immersed in a marsh area on the border of the lake, and at least three were usually observed while basking over logs partially submerged. One individual of $P$. geoffroanus released a strong-smelling musk when captured (later released).

Platemys platycephala was recorded in five occasions, always walking in non-flooded and seasonally flooded forest by day. At non-flooded forest, it was usually near shallow streams. One individual was found in 09 August 1999 during day among the leaf-litter near to a small rivulet in primary non-flooded forest; it was examined and released, having a carapace length of $117 \mathrm{~mm}$, maximum plastral length of $109 \mathrm{~mm}$, carapace width of $80 \mathrm{~mm}$, head length of $41 \mathrm{~mm}$, and weight of $139.5 \mathrm{~g}$. Individuals observed coincides well with the description of the subspecies Platemys platycephala melanonota by Ernst (1983). Chelus fimbriatus was observed once at TBS during late afternoon on August 2000, moving in a shallow swamp located behind the oxbow lake of TBS.
Few localities for members of the family Chelidae in Ecuador have been mentioned in the literature, so in addition to the TBS records, I report herein some new localities. One specimen of Batrachemys raniceps was collected at Shushufindi (00²' '43" S, 76³9'29" W, 220 $\mathrm{m})$, province of Sucumbíos, by J.-M. Touzet on 02 October 1996 (FHGO 1481). Batrachemys raniceps was first reported in Ecuador by Miyata (1982) without mentioning a locality, and I could not locate additional published records for the species in Ecuador; thus the species is apparently reported in Ecuador just from the provinces of Sucumbíos and Orellana (Figure 1). Two specimens of Chelus fimbratus were collected at Laguna Grande, Cuyabeno Reserve (0005’ S,76¹0’ W, 220 m), province of Sucumbíos, by F. Campos on 25 December 1989 (FHGO 206) and 25 February 1990 (FHGO 207). Chelus fimbriatus was reported by Orcés (1949) from localities in the province of Zamora-Chinchipe and Sucumbíos; by Duellman (1978) from the province of Sucumbíos, and Iverson (1992) 
plotted a locality in the province of Pastaza; therefore the distribution of $C$. fimbratus apparently comprises the entire Amazonian Ecuador, with confirmed records from the provinces of Sucumbíos, Orellana, Pastaza, and Zamora-Chinchipe (Figure 2). One specimen of Mesoclemmys gibba was collected at Shushufindi (00¹2’43" S, 76³9'29" W, 220 m), province of Sucumbíos, by J.-M. Touzet on 20 September 1987 (FHGO-live 037), and one individual was observed at the Laguna Grande, Cuyabeno Reserve ( $\left.00^{\circ} 05^{\prime} \mathrm{S}, 76^{\circ} 10^{\prime} \mathrm{W}, 220 \mathrm{~m}\right)$, province of Sucumbíos, by the author on August 2000. Messoclemys gibba has been reported from the province of Sucumbíos (Duellman 1978, Pritchard \& Trebbau 1984), from the province of Orellana and Pastaza (Pritchard \& Trebbau 1984, Iverson 1992), and more recently from the province of Napo (Deforce et al. 2004). Therefore, Messoclemys gibba has confirmed records in northern Amazonian Ecuador, in the provinces of Napo, Sucumbíos, Orellana and Pastaza (Figure 3). One specimen of Phrynops geoffroanus was collected at the Hollín River (Hollín-Loreto road), near Tena (ca. 0041' S, 7740' W), province of Napo, by M. Mamallacta on 15 July 1998 (FHGO-live 2188). Orcés (1949) cited this species as " $P$. hilari" from the province of Napo (localities also mentioned by Pritchard \& Trebbau 1984), and was reported from the province of Sucumbíos by Duellman (1978) and Pritchard \& Trebbau (1984). Thus, Phrynopus geoffroanus has been recorded in Ecuador from the provinces of Napo, Sucumbíos, and Orellana (Figure 4). The absence of records of $M$. gibba and $P$. geoffroanus in southern Amazonian Ecuador could reflect the paucity of surveys in these area rather than real absence or rarity. One specimen of Platemys platycephala was collected at San Pablo de Kantesiaya (00¹5’00" S, 76²5’30" W, $240 \mathrm{~m}$ ), province of Sucumbíos, by J.-M. Touzet on 01 February 1987 (FHGO-live 122), and another was collected at the Shiripuno River (sector Noneno) $\left(01^{\circ} 05^{\prime} \mathrm{S}\right.$, 76 $6^{\circ} 50^{\prime} \mathrm{W}$ ), province of Pastaza, by J.-M. Touzet on 30 August 1997 (FHGO 2261). Platemys platycephala was reported by Orcés (1949) from the province of Orellana and Pastaza, Duellman (1978) reported the species from the province of Sucumbíos, and Pritchard \& Trebbau (1984) mentioned records from the provinces of Orellana, Napo, Sucumbíos, Pastaza, and Morona-Santiago (Pritchard \& Trebbau [1984] cited the locality of Macuma (=Makuma) in the province of Zamora-Chinchipe, however it is located in the province of Morona-Santiago). Almendáriz (1987) reported the species from the province of Pastaza and Iverson (1992) and Ernst (1983) plotted several localities, especially in southeastern Ecuador. Platemys platycephala has the widest reported distribution in eastern Ecuador, with confirmed records at every Amazonian province: Napo, Sucumbíos, Orellana, Pastaza, Morona-Santiago and Zamora-Chinchipe (Figure 5).
The family Kinosternidae is represented at TBS by one species, Kinosternon scorpioides (Linnaeus). One $K$. scorpioides was observed among the border vegetation at the drainage of a rivulet, tributary of the Tiputini River, and a second turtle was captured (late released) while walking amidst leaf-litter on the margin of the same rivulet. Orcés (1949) reported the species from the province of Orellana, and Duellman (1978) and Pritchard \& Trebbau (1984) from the province of Sucumbíos. Kinosternon scorpioides has confirmed records along northern Amazonian Ecuador, in the provinces of Sucumbíos and Orellana (Figure 2).

Two species of the family Podocnemididae occur at TBS, Podocnemis expansa (Schweigger) and P. unifilis Troschel. Podocnemis expansa was the rarest among them, with just two direct observations of two big-size adults basking on a partially submerged tree at the Tiputini River, near the beach, plus the observation of at least two nests along the beaches of the Tiputini River on August 1999. The carapace of an adult $P$. expansa (kept at the laboratory of the station) had a length of $780 \mathrm{~mm}$ and was obtained ca. 1995 near TBS. Podocnemis unifilis was the most observed turtle along the Tiputini River and at the oxbow lake. Groups up to 12 adult or juvenile individuals were frequently observed basking over partially submerged logs or along vegetation near the border of the river or lake. Several nests were observed at the beaches of the Tiputini River. On one occasion, up to four nests were attacked at the same beach by a couple of Black Caracaras (Daptrius ater) and by a Tegu Lizard (Tupinambis teguixin). Eggs of $P$. unifilis (and probably $P$. expansa) were extracted occasionally from nests by native inhabitants, even though this practice is illicit in that section of the Tiputini River.

The only tortoise at TBS is Geochelone denticulata (Linnaeus). This tortoise was rather common, especially at non-flooded primary forest, but also at flooded primary forest (during low flood periods). Five to eight individual records were obtained each year between 1997 and 2001. Individuals were found walking usually during early and late afternoon. Most tortoises had ticks on the carapace. Five individuals found in year 2000 (January, April and August) were measured, showing a mean carapace length of $410.8 \pm 75.0 \mathrm{~mm}$ (range $475.0-310.0 \mathrm{~mm}$ ), mean carapace width of $327.5 \pm 85.4 \mathrm{~mm}$ (range $380.0-200.0 \mathrm{~mm}$ ), and maximum plastral length of $287.7 \pm 55.5 \mathrm{~mm}$ (range 336.0 - 227.0 $\mathrm{mm}$ ). Orcés (1949) reported this species from the provinces of Sucumbíos, Orellana, and Pastaza; Duellman (1978) reported it from the province of Sucumbíos; Pritchard \& Trebbau (1984) reported G. denticulata from the provinces of Sucumbíos and Morona-Santiago; and Almendáriz (1987) reported it from the province of Pastaza. I have observed this species at several localities near Tarapoa (ca. $00^{\circ} 08^{\prime} \mathrm{S}$, $76^{\circ} 24^{\prime}$ W, ca. $300 \mathrm{~m}$ ), province of Sucumbíos, near Puyo (ca. $01^{\circ} 28^{\prime} \mathrm{S}, 77^{\circ} 59^{\prime} \mathrm{W}$, ca. $950 \mathrm{~m}$ ), province of Pastaza, and on the Macas-Puyo road (ca. $02^{\circ} 19^{\prime}$ S, $78^{\circ} 07^{\prime} \mathrm{W}$ ), province of 
Morona-Santiago. Thus, Geochelone denticulata has been reported from almost every province in Amazonian Ecuador (Napo, Sucumbíos, Orellana, Pastaza and Morona-Santiago) except for the province of Zamora-Chinchipe (Figure 6).

Although two species of the genus Podocnemis ( $P$. unifilis and $P$. expansa) are usually regarded as the only members of the family Podocnemididae in Ecuador, Orcés (1949) reported Peltocephalus dumerilianus (Schweigger) from Ecuador based on five specimens from the province of Pastaza, and one juvenile with uncertain locality. The identity of those specimens has never been confirmed, nor the specimens examined again; and just Iverson (1992) and Iverson \& Vogt (2002) accepted those records. Miyata (1982), Almendáriz (1991) and Coloma et al. (2000-2004) did not included $P$. dumerilianus in their lists of Ecuadorian reptiles. Two out of six specimens reported by Orcés (1949) were located at the collection of the Colegio Mejia, Quito; they correspond well with $P$. dumerilianus and confirmed the presence of this species in the Republic of Ecuador, with records at least in the province of Pastaza. Medem (1960) reported $P$. dumerilianus from the Apaya lagoon, near Puerto Leguizamo, on the Putumayo River, not far from the border of Colombia with Ecuador (ca. $20 \mathrm{~km}$ ); therefore, $P$. dumerilianus could also exist in the wetlands of eastern Sucumbíos, Ecuador. The Ecuadorian richness of Chelonian species increases to 31 living taxa with the recognition of Peltocephalus dumerilianus, with 11 species distributed in the Amazonian lowlands. As several nomenclatural and systematic changes have occurred affecting the classification of Ecuadorian turtles and tortoises, I present an annotated list of the turtles and tortoises from mainland and insular Ecuador in Appendix 1.

The total chelonian diversity at the Tiputini Biodiversity Station comprises ten species, from four different families: Chelidae, Kinosternidae, Podocnemididae, and Testudinidae. Data presented herein suggest that although most chelonians at TBS are sympatric, they are not completely syntopic; this case is especially evident in the four toadhead turtles, supporting hypotheses presented by McCord et al. (2001) on habitat preferences. The shallow swamps in non-flooded areas (behind oxbow lake) were occupied in syntopy by Batrachemys heliostemma and Chelus fimbriatus. Small drainages and ephemeral marshes in flooded areas were the habitat of Batrachemys raniceps and Mesoclemmys gibba. Non-flooded and seasonally flooded forests, including hill areas far from the Tiputini River, were inhabited by Platemys platycephala and Geochelone denticulata. Open waters of the oxbow lake were inhabited by Phrynopus geoffroanus and Podocnemis unifilis, while at small drainages $P$. geoffroanus was in syntopy with Kinosternon scorpioides; and at the river with both members of the family Podocnemididae, Podocnemis expansa and $P$. unifilis. Podocnemis expansa is an exclusive inhabitant of the river (Figure 7).
However, much information is still needed in order to understand the ecological relationships of these sympatric Testudines. Little information is available on the life cycles of the Amazonian species, including egg deposition sites, nesting periods, environmental requirements for successful egg development, predation effects over nests, emergence period of neonates, behavior of neonates, ontogenic changes in habitat, microhabitat and time use patterns, movement patterns, maturity time for males and females, sex ratio, survivorship and longevity (Gibbons 1990, Burke et al. 2000). Future research at TBS and other research stations along Amazonian Ecuador should focused on longterm studies designed to answer these biological and ecological questions.

Several threats are currently jeopardizing the longterm conservation of turtle populations along the planet. Habitat alteration, pollution, human exploitation, diseases and introduced species are causal factors for the declines of several turtles (Burke et al. 2000). Podocnemis expansa is an explicit case of the fragility of the turtle populations in Amazonian Ecuador. The extreme and uncontrolled overexploitation of this giant river turtle has reduced its numbers to the point that its long-term survivorship is uncertain. Several conservation efforts, including sustainable harvesting, protection and management of nests, have been established in Ecuador for the economically-relevant species of the genus Podocnemis, but research and conservation efforts focused on every turtle taxon must be established in Ecuador. We must increase our knowledge on these amazing animals in order to protect and preserve them.

\section{Acknowledgments}

I am grateful to the staff of the Tiputini Biodiversity Station, Universidad San Francisco de Quito, especially to David Romo, Consuelo Barriga de Romo, Kelly Swing, Mayer Rodríguez and Franklin Narváez, for their continuous support during my field work; and to Jean-Marc Touzet and Ana María Velasco for allowing access to material and information at the FHGO. I thank Ana Almendáriz, John Iverson, Stephen Karl, the Savanna River Ecology Laboratory, the Charles Darwin Foundation, and the Department of Vertebrate Zoology, Smithsonian Institution, for providing useful literature or access to their libraries. I am extremely grateful to María Elena Heredia and Laura Heredia for their continuous moral and financial support. Field work was partially financed by the Tiputini Biodiversity Station, Universidad San Francisco de Quito, lab work by the Universidad San Francisco de Quito, and work at the Smithsonian Institution by the 2002 Research Training Program, National Museum of Natural History and Smithsonian's Women Committee. 


\section{References}

ALMENDÁRIZ, A. 1987. Contribución al conocimiento de la herpetofauna centroriental Ecuatoriana. Revista Politécnica Quito XII (4):77-133.

ALMENDARIZ, A. 1991. Anfibios y reptiles. In Lista de Vertebrados de Ecuador (R. Barriga, A. Almendáriz \& L. Albuja, eds.). Revista Politécnica XVI (3):89-162.

ALMENDARIZ, A. \& CARR, J. L. 1992. Amphibians and Reptile List; January-February Trip. In Status of Forest Remnants in the Cordillera de la Costa and Adjacent Areas of Southwestern Ecuador (T. A. Parker III \& J. L. Carr, eds.). Conservation International, RAP Working Paper 2, p.128-130.

BOUR, R. 1980. Essai sur la taxonomie des Testudinidae actuels (Reptilia, Chelonii). Bull. Mus. Nat. Hist. Nat. 4(2):541-546.

BOWEN, B. W. \& KARL, S. A. 1997. Population Genetics, Phylogeography, and Molecular Evolution. In The Biology of Sea Turtles (Lutz, P. L. \& Musick, J. A., eds.). CRC Press, Boca Raton, p.29-50.

BOWEN, B. W. \& KARL, S. A. 1999. In War, Truth is the First Casualty. Conservation Biology 13(5):1013-1016.

BOWEN, B. W. \& KARL, S. A. 2000. Meeting Report: Taxonomic Status of the East Pacific Green Turtle (Chelonia agassizii). Marine Turtle Newsletter 89:20-22.

BURKE, V. J., LOVICH, J. E. \& GIBBONS, J. W. 2000. Conservation of Freshwater Turtles. In Turtle Conservation (M. Klemens, ed.). Smithsonian Institution Press, Washington, D.C., p.156-179.

CACCONE, A., GENTILE, G., GIBBS, J.P., FRITTS, T.H., SNELL, H.L., BETTS, J. \& POWELL, J.R. 2002. Phylogeography and history of Giant Galápagos Tortoises. Evolution 56(10): 2052-2066.

CACCONE, A., GIBBS, J.P., KETMAIER, V., SUATONI, V. \& POWELL, J.R. 1999. Origin and evolutionary relationships of giant Galápagos tortoises. PNAS 96(23): 13223-13228.

CARR, J. L. \& ALMENDÁRIZ, A. 1989. Contribución al Conocimiento de la Distribución Geográfica de los Quelonios del Ecuador Continental. Revista Politécnica XIV (2):75-103.

COLOMA, L.A., QUIGUANGO, A. \& RON, S. 2000-2004. Reptiles de Ecuador: lista de especies y distribución. Crocodylia, Serpentes y Testudines. [on line]. Ver. 1.1. (25 May 2000). Museo de Zoología, Pontificia Universidad Católica del Ecuador, Quito, http:// www.puce.edu.ec/Zoologia/repecua.htm (Last accessed on 22 May 2005).

DEFORCE, E.A., DEFORCE, C. D. \& LIDERMAN, P. V. 2004. Phrynops gibbus (Gibba Turtle). Trap-happy Behavior. Herpetological Review 35(1):55-56.
DIAMOND, A. W. 1976. Breeding biology and conservation of Hawksbill turtles, Eretmochelys imbricata L., on Cousin Island, Seychelles. Biological Conservation 9(3):199-215.

DUELLMAN, W. E. 1978. The Biology of an Equatorial Herpetofauna in Amazonian Ecuador. University of Kansas, Miscellaneous Publication 65, p.1-352.

DUTTON, P. H., DAVIS, S. K., GUERRA, T. \& OWENS, D. 1996. Molecular Phylogeny for Marine Turtles Based on Sequences of the ND4-Leucine tRNA and Control Regions of Mitochondrial DNA. Molecular Phylogenetics and Evolution 5(3):511-521.

ERNST, C. H. 1983. Geographic Variation in the Neotropical Turtle, Platemys platycephala. Journal of Herpetology 17 (4): 345-355.

GIBBONS, J. W. 1990. Recommendations for future research on freshwater turtles: What are the Questions. In Life History and Ecology of the Slider Turtle. (Gibbons, J. W., ed.). Smithsonian Institution Press, Washington, D.C., p. 311-317.

HEYER, W. R., DONNELLY, M. A., MCDIARMID R. W., HAYEK, L. A. C. \& FOSTER, M. S. 1994. Measuring and Monitoring Biological Diversity - Standard Methods for Amphibians. Smithsonian Institution Press, Washington, D.C.

IVERSON, J. B. 1992. A revised Checklist with Distribution Maps of the Turtles of the World. Richmond (Privately printed).

IVERSON, J. B. \& VOGT, R. C. 2002. Peltocephalus, P. dumerilianus. Catalogue of American Amphibians and Reptiles 744: 1-4.

KARL, S. A. \& BOWEN, B. W. 1999. Evolutionary Significant Units versus Geopolitical Taxonomy: Molecular Systematics of an Endangered Sea Turtle (genus Chelonia). Conservation Biology 13 (5): 990-999.

MCCORD, W. P., OUNI, M. J. \& LAMAR, W. W. 2001. A Taxonomic Reevaluation of Phrynops (Testudines: Chelidae) with the description of two new genera and a new species of Batrachemys. Revista de Biología Tropical, San José; 49 (2): 715-764.

MCFARLAND, C. G., VILLA, J. \& TORO, B. 1974. The Galápagos Giant tortoises (Geochelone elephantopus) Part I: Status of the Surviving Populations. Biological Conservation 6(2): 118-133.

MEDEM, F. 1960. Datos Zoo-geográficos y ecológicos sobre los Crocodylia y Testudinata de los ríos Amazonas, Putumayo y Caquetá. Caldasia VIII (38): 341-351.

MEYLAN, P.A. 1996. Skeletal morphology and relationships of the Early Cretaceous side-necked turtle, Araripemys barretoi (Testudines: Pelomedusoides: Araripemydidae), from the Santana Formation of Brazil. Journal of Vertebrate Paleontology $16(1): 20-33$. 
MIYATA, K. 1982. A Check List of the Amphibians and Reptiles of Ecuador with a Bibliography of Ecuadorian Herpetology. Smithsonian Herpetological Information Service 54: 1-69.

OKAYAMA, T., DIAZ-FERNANDEZ, R., BABA, Y., HALIM, M., ABE, O., AZENO, N. \& KOIKE, H. (1999). Genetic diversity of the Hawksbill Turtle in the Indo-Pacific and Caribbean regions. Chelonian Conservation and Biology 3(2): 362-367.

ORCÉS V., G. 1949. Los Testudinata Ecuatorianos que se conservan en las colecciones de Quito, Ecuador. Boletín de Informaciones Científicas Nacionales III (20/21): 13-22.

PHILLIPS, C. A., DIMMICK, W. W. \& CARR, J. L. 1996. Conservation Genetics of the Common Snapping Turtle (Chelydra serpentina). Conservation Biology $10(2): 397-405$.

PRITCHARD, P. C. H. 1980. Dermochelys coriacea. Catalogue of American Amphibians and Reptiles 238: 1-4.

PRITCHARD, P.C.H. 1996. The Galapagos Tortoises. Nomenclatural and Survival Status. Chelonian Research Foundation in association with Conservation International and Chelonia Institute.

PRITCHARD, P. C. H. 1999. Status of the Black Turtle. Conservation Biology 13(5): 1000.

PRITCHARD, P. C. H. \& TREBBAU, P. 1984. The Turtle of Venezuela. Society for the Study of Amphibians and Reptiles, Contributions to Herpetology, No. 2.

RUSSELLO, M.A., GLABERMAN, S., GIBBS, J.P., MARQUEZ, C., POWELL, J.R. \& CACCONE, A. 2005. A cryptic taxon of Galáapagos tortoise in conservation peril. Biology Letters (2005) 1: 287-290.

SITES, JR., J. W. \& K. A. CRANDALL. 1997. Testing Species Boundaries in Biodiversity Studies. Conservation Biology 11(6): 1289-1297.

SPINKS, P. Q., SHAFFER, H. B., IVERSON, J. B. \& MCCORD, W. P. 2004. Phylogenetic hypotheses for the turtle family Geoemydidae. Molecular Phylogenetics and Evolution 32 (1): 164-182.

WALKER, D., MOLER, P. E., BUHLMANN, K.A. \&AVISE, J. C. 1998. Phylogeographic uniformity in mitochondrial DNA of the snapping turtle (Chelydra serpentina). Animal Conservation 1998 (1): 55-60.

YASUKAWA, Y., HIRAYAMA, R. \& HIKIDA, T. 2001. Phylogenetic relationships of geoemydine turtles (Reptilia: Bataguridae). Current Herpetology 20: 105-133.
Title: Turtles of the Tiputini Biodiversity Station with remarks on the diversity and distribution of the Testudines from Ecuador.

Author: Diego F. Cisneros-Heredia

Biota Neotropica, Vol. 6 ( number 1): 2006

http://www.biotaneotropica.org.br/v6n1/pt/ abstract?inventory+bn00906012006

Date Received 05/23/2005 - Revised 10/18/2005

Accepted 01/01/2006

ISSN 1676-0611 


\section{APPENDIX 1.}

Annotated Checklist of the living Testudines (turtles and tortoises) from mainland and insular Ecuador.

\section{FAMILY CHELIDAE}

Notes: All species of toad-head turtles were included in the genus Phrynops until the revision of McCord et al. (2001) whom resurrected the genera Batrachemys, Mesoclemmys and Rhinemys from its synonymy.

1. Batrachemys heliostemma McCord, Ouni \& Lamar, 2001

Distribution in Ecuador: Eastern Tropical (Amazonia). Provinces of Sucumbíos and Orellana.

\section{Batrachemys raniceps (Gray, 1855)}

Distribution in Ecuador: Eastern Tropical (Amazonia). Provinces of Sucumbíos and Orellana.

Notes: Previously under the synonymy of Batrachemys (Phrynops) nasuta.

3. Chelus fimbriatus (Schneider, 1783)

Distribution in Ecuador: Eastern Tropical (Amazonia). Provinces of Sucumbíos, Orellana, Pastaza, and Zamora-Chinchipe.

\section{Mesoclemmys gibba (Schweigger, 1812)}

Distribution in Ecuador: Eastern Tropical (Amazonia). Provinces of Napo, Sucumbíos, Orellana and Pastaza.

\section{Platemys platycephala (Schneider, 1792)}

Distribution in Ecuador: Eastern Tropical (Amazonia). Provinces of Napo, Sucumbíos, Orellana, Pastaza, MoronaSantiago, and Zamora-Chinchipe.

Notes: Ecuadorian populations are assigned to the subspecies Platemys platycephala melanonota Ernst.

\section{Phrynops geoffroanus (Schweigger, 1812)}

Distribution in Ecuador: Eastern Tropical (Amazonia). Provinces of Napo, Sucumbíos, and Orellana.

\section{FAMILY CHELONIIDAE}

\section{Chelonia mydas Bocourt, 1868}

Distribution in Ecuador: Pacific coast of Ecuador (including surrounding islands) and Galápagos Archipelago.

Notes: The Ecuadorian populations have been assigned to the subspecies Chelonia mydas agassizii_Bocourt 1868, which is considered by some authors (eg. Pritchard 1999) as a species, different from mydas: Chelonia agassizii. However, there is still much controversy regarding the real differentiation of populations assigned to the taxon agassizii from those assigned to mydas, and its real taxonomic status (see Bowen \& Karl 1997, 1999, Karl \& Bowen 1999, Pritchard $\underline{1999}$, Bowen \& Karl 2000). As the black turtle agassizii is considered "unique in some respect and is likely to be an emerging evolutionary lineage” (Bowen \& Karl 2000), I herein maintained the subspecific status (as Chelonia mydas agassizii) for the East Pacific populations (including Ecuador), pending further studies.

\section{Eretmochelys imbricata (Linnaeus, 1766)}

Distribution in Ecuador: Pacific coast of Ecuador (including surrounding islands) and Galápagos Archipelago.

Notes: The name Eretmochelys imbricata bissa (Rüppell) (with squamata Agassiz as a synonym) has been assigned by several authors to the Indo-Pacific populations, including the Ecuadorian (see Pritchard and Trebbau 1984). The intra-specific variation of Eretmochelys imbricata is still insufficiently known, and the subspecific status has been questioned by some authors (see Diamond 1976). Okayama et al. (1999) found that the distribution of the mtDNA haplotype diversity is consistent with the fundamental division between the Atlantic and Pacific populations, but also found significant lineage segregation within the Indo-Pacific stock (Okayama et al., 1999). The subspecies division is herein maintained until more studies provide a more complete understanding of the species variation and systematics.

\section{Lepidochelys olivacea (Eschscholtz, 1829)}

Distribution in Ecuador: Pacific coast of Ecuador (including surrounding islands) and Galápagos Archipelago.

\section{FAMILY CHELYDRIDAE}

10. Chelydra serpentina (Linnaeus, 1758)

Distribution in Ecuador: Western Tropical. Provinces of Esmeraldas, Manabí, Guayas, Los Ríos, Pichincha.

Notes: Ecuadorian populations are assigned to the subspecies C. s. acutirostris Peters. However, the taxonomic status of the different names under Chelydra serpentina is still controversial. Currently four subspecies are recognized for C. serpentina: C. s. serpentina, C. s. acutirostris, C. s. osceola, and C. s. rossignonii. The North American taxa (nominal subspecies and osceola) have been considered either as synonyms or as subspecies but further studies are needed (Phillips et al. 1996, Walker et al. 1998, Sites \& Crandall 1997). Much controversy still exists on the status of the Central and South American populations; Phillips et al. (1996) suggested specific status for both taxa (acutirostris and rossignonii) based on patterns of geographic variation in isozyme and mitochondrial DNA restriction fragment pattern data; but Sites \& Crandall (1997) presented an alternative interpretation of their data and concluded that species status may not be guaranteed for Central and South American taxa, but that the Ecuadorian population may deserve species status if the fixation of a unique allele at two nuclear isozyme loci (M-Icdh and S-Icdh) is showed to be present with more extensive sampling; however additional studies have not been performed yet and the subspecies status is maintained for the Ecuadorian population. 
Several specimens of Chelydra serpentina have been found in places outside its previously reported distribution range (ej. Los Frailes, Machalilla National Park, province of Manabí - FHGO 713; La Maná, province of Cotopaxi - not preserved). However, the validity of these records is uncertain because they could correspond to animals transported by illegal traffic, rather than a real extension in the distribution range of the species (ej., Geochelone denticulata reported by Orcés [1949] from western Ecuador). Illegal traffic of turtles in Ecuador has involved several thousands of freshwater turtles and tortoises over the years. The extensive commerce towards the biggest cities (ej., Quito and Guayaquil) was stopped (or at least minimized) in the late90 's through a public campaign to stop wildlife traffic; however, several dozens are still captured for the pet markets in small-medium towns. Illegal traffic involves almost any mainland species, but the most common-captured species are: Geochelone denticulata, Chelydra serpentina, Kinosternon leucostomum, and Rhinoclemmys spp. Further, thousands of specimens of Trachemys spp. are exported into Ecuador for the legal pet market, and several of those turtles are released into Ecuadorian wetlands when people are unable to care them. It is unknown if there is any population of Trachemys spp. established in Ecuador and the consequences on the native wildlife.

\section{FAMILY DERMOCHELYIDAE}

\section{Dermochelys coriacea (Vandelli, 1761)}

Distribution in Ecuador: Pacific coast of Ecuador (including surrounding islands) and Galápagos Archipelago.

Notes: Some authors recognized two subspecies inside Dermochelys coriacea, the nominal and schlegelii (Garman) (with augusta [Philippi] as a synonym); with the nominal subspecies for the Atlantic populations and schlegelii assigned to the Indo-Pacific populations. Although differences between Eastern Pacific and Atlantic populations have been mentioned (Pritchard and Trebbau 1984), low genetic variation was showed in analyses of mtDNA sequence divergence between Pacific and Atlantic populations (Dutton et al. 1996); and currently Dermochelys coriacea is recognized as monotypic, without subspecific divisions (Pritchard 1980, Pritchard and Trebbau 1984).

\section{FAMILY GEOEMYDIDAE}

Notes: The family Geoemydidae (with Bataguridae as a junior synonym) was previously considered a subfamily inside Emydidae, however currently both are considered as separate families; with Emydidae as the sister group of a Geoemydidae/Testudinidae clade (Spinks et al. 2004).

12. Rhinoclemmys annulata (Gray, 1860)

Distribution in Ecuador: Western Tropical. Provinces of Esmeraldas, Manabí, Guayas, Los Ríos, Imbabura, Pichincha.
Notes: This species was separated into the resurrected genus Chelopus by Yasukawa et al. (2001), however recent analysis strongly suggest that the genus Rhinoclemmys (including annulata) is monophyletic and the recognition of the genus Chelopus is not justified (Spinks et al. 2004).

\section{Rhinoclemmys melanosterna (Gray, 1861)}

Distribution in Ecuador: Northwestern Tropical. Province of Esmeraldas.

Notes: Records of Rhinoclemmys melanosterna (ej. Puerto Cayo-Puerto Nuevo road, Manabí - FHGO 1335, Manta-Eloy Alfaro road, Manabí - FHGO 1478) and $R$. nasuta (record from the Machalilla National Park reported by Almendáriz \& Carr 1992) from outside their currently known distribution ranges must be evaluated carefully, as they can be product of artificial introductions rather than reflect the real distribution of the species (see notes under Chelydra serpentina).

14. Rhinoclemmys nasuta (Boulenger, 1902)

Distribution in Ecuador: Northwestern Tropical. Provinces of Esmeraldas and Pichincha.

Notes: See notes under Rhinoclemmys melanosterna.

\section{FAMILY KINOSTERNIDAE}

15. Kinosternon leucostomum Duméril \& Bibron, 1851

Distribution in Ecuador: Western Ecuador. Provinces of Esmeraldas, Guayas, Los Ríos, Pichincha, and Cañar.

Notes: Ecuadorian population is assigned to the subspecies Kinosternon leucostomum postinguinale_(Cope). Records of Kinosternon leucostomum from outside its currently known distribution range must be evaluated carefully, as they can be product or artificial introductions rather than reflect the real distribution of the species (see notes under Chelydra serpentina).

\section{Kinosternon scorpioides (Linnaeus, 1766)}

Distribution in Ecuador: Eastern Tropical (Amazonia). Provinces of Sucumbíos and Orellana.

Notes: Ecuadorian populations are assigned to the subspecies Kinosternon scorpioides scorpioides (Linnaeus).

\section{FAMILY PODOCNEMIDIDAE}

Notes: The family Podocnemididae was previously considered a subfamily inside Pelomedusidae, but currently the Malagasy and American species are in the family Podocnemididae and just the African species in the family Pelomedusidae (see Meylan 1996)

\section{Podocnemis expansa (Schweigger, 1812)}

Distribution in Ecuador: Eastern Tropical (Amazonia). Provinces of Sucumbíos, Napo, Orellana, and Pastaza. 
Notes: Ecuadorian populations are critically endangered and on the brink of extinction.

\section{Podocnemis unifilis Troschel, 1848}

Distribution in Ecuador: Eastern Tropical (Amazonia). Provinces of Sucumbíos, Napo, Orellana, Pastaza and Morona-Santiago.

19. Peltocephalus dumerilianus (Schweigger, 1812)

Distribution in Ecuador: Eastern Tropical (Amazonia). Province of Pastaza.

Notes: First reported from Ecuador by Orcés (1949).

\section{FAMILIA TESTUDINIDAE}

Notes: All Ecuadorian species of the family Testudinidae are members of the subgenus Chelonoidis, which has been accorded generic status by some authors (ej. Bour 1980). The taxonomic arrangement of the Galapagos tortoises is not completely settled:

(1) Some authors relegate all Galapagos tortoise taxa as subspecies of a single species, usually named G. nigra or G. elephantopus.

(2) The populations from southern Isla Isabela (Darwin and Alcedo Volcanoes, Cerro Azul, Sierra Negra) are problematic. Pritchard (1996) suggested that the four southern Isla Isabela taxa do not warrant separate status. Caccone et al. (1999) found that those populations lack genetic differentiation; but latter, Caccone et al. (2002) found that microphyes (Volcan Darwin) and vandenburghi (Volcan Alcedo) are genetically distinct, and deserve separation; but they can not refute the suggestion that the two southern most subspecies are not genetically distinct.

(3) It was recently recognized that the Isla San Cruz populations, formerly recognized as the single taxon nigrita (with porteri as a synonym), include three distinct lineages, with at least one deserving its recognition as a new and endangered taxon (Russello et al. 2005).

20. Geochelone abingdonii (Günther, 1877) Isla Pinta.

Distribution in Ecuador: Galápagos Archipelago,

Notes: Only survivor (Lonesome George) lives at the Charles Darwin Research Station.

21. Geochelone becki (Rothschild, 1901)

Distribution in Ecuador: Galápagos Archipelago, Isla Isabela (Wolf volcano).

22. Geochelone chathamensis (Van Denburgh, 1907)

Distribution in Ecuador: Galápagos Archipelago, Isla San Cristobal.

23. Geochelone darwini (Van Denburgh, 1907)

Distribution in Ecuador: Galápagos Archipelago, Isla San Salvador.

24. Geochelone denticulata (Linnaeus, 1766)
Distribution in Ecuador: Eastern Tropical (Amazonia). Provinces of Sucumbíos, Napo, Orellana, Pastaza and Morona-Santiago.

Notes: Records from Western Ecuador are certainly specimens transported by illegal traffic (Carr \& Almendáriz 1989, also see notes under Chelydra serpentina).

It has been suggested that Geochelone carbonaria (Spix) could occur in Ecuador (Vanzolini in Miyata 1982, P. Salvador pers. comm.), however no voucher specimens are known.

25. Geochelone ephippium_Günther, 1875)

Distribution in Ecuador: Galápagos Archipelago, Isla Pinzón.

26. Geochelone guntheri (Baur, 1890)

Distribution in Ecuador: Galápagos Archipelago, Isla Isabela (Sierra Negra).

27. Geochelone hoodensis (Van Denburgh, 1907)

Distribution in Ecuador: Galápagos Archipelago, Isla Española.

28. Geochelone microphyes (Günther, 1875)

Distribution in Ecuador: Galápagos Archipelago, Isla Isabela (Darwin volcano).

29. Geochelone nigrita (Duméril \& Bibron, 1835)

Distribution in Ecuador: Galápagos Archipelago, Isla Santa Cruz.

30. Geochelone vandenburghi (DeSola, 1930)

Distribution in Ecuador: Galápagos Archipelago, Isla Isabela (Alcedo volcano).

31. Geochelone vicina (Günther, 1875)

Distribution in Ecuador: Galápagos Archipelago, Isla Isabela (Cerro Azul).

http://www.biotaneotropica.org.br 